\title{
Korupsi State Capture Sebagai Crime Against Humanity
}

\author{
Hana Ramiza \\ hana.ramiza-2015@fh.umair.ac.id \\ Universitas Airlangga
}

\begin{abstract}
Keywords:
\section{Abstract}

Corruption; State Corruption is a problem that has been recognized by the international community and Capture; Crime not only inflicts financial loss but also frequently violates human rights. Its systematic, Against Humanity; planned and widespread nature generates an opinion that corruptions resulted in appalling Rome Statute; International aftermath as though torture, genocide and other crimes against humanity and as such,

Criminal Court. must be determined as a crime against humanity. This article aims to answer the issue of the crime of corruption to be categorized as a crime against humanity using doctrinal research method. A form of corruption known as state capture has elements that meets the criteria of crimes against humanity as regulated in Rome Statute and as such, corruptionespecially state capture - can be can be categorized as crime against humanity. With the establishment of corruption as a crime against humanity, the perpetrators of this crime would be able to be held liable for criminal liability under the international law through international criminal court or ad hoc international criminal court.
\end{abstract}

\begin{abstract}
Kata Kunci: Korupsi; State Capture; Crime Abstrak Against Humanity; Statuta Roma; International Criminal Court.

Korupsi merupakan masalah yang telah diakui oleh komunitas internasional dan tidak hanya menyebabkan kerugian bagi finansial negara, namun juga sarat akan pelanggaran hak asasi manusia. Sifatnya yang sistematis, terencana dan luas membuat munculnya pendapat bahwa korupsi menimbulkan akibat yang mengerikan layaknya penyiksaan, genosida dan kejahatan terhadap kemanusiaan lainnya dan harus ditetapkan sebagai crime against humanity. Artikel ini bertujuan untuk menjawab isu mengenai sifat dan akibat yang ditimbulkan oleh tindak pidana korupsi untuk dapat dikategorikan sebagai crime against humanity dengan menggunakan metode penelitian doctrinal research. Sebuah bentuk korupsi yaitu state capture memiliki elemen-elemen yang sesuai dengan crime against humanity sebagaimana diatur dalam Statuta Roma sehingga dengan demikian, korupsi khususnya state capture dapat dikategorikan sebagai crime against humanity. Dengan ditetapkannya korupsi sebagai crime against humanity, maka individu-individu yang terlibat tindak pidana korupsi akan dapat dimintai pertanggungjawaban pidana di bawah hukum internasional melalui international criminal court atau melalui pengadilan pidana internasional ad hoc.
\end{abstract}

Copyright (C) 2020 Universitas Airlangga

\section{Pendahuluan}

Dalam buku "Menyingkap Korupsi, Kolusi, dan Nepotisme di Indonesia", Taufik Abdullah memiliki pendapat bahwa apabila benar prostitusi merupakan profesi tertua, maka korupsi dan kolusi barangkali boleh juga dikatakan sebagai 
sama tuanya dengan organisasi yang memiliki kekuatan (organization of power). ${ }^{1}$ Pada perkembangannya, korupsi tidak lagi dianggap merugikan bagi keuangan atau perekonomian negara saja, melainkan juga dianggap oleh pemerintah Indonesia telah melanggar hak-hak sosial dan ekonomi masyarakat secara luas sehingga tindak pidana ini digolongkan sebagai kejahatan yang pemberantasannya harus dilakukan secara luar biasa. ${ }^{2}$

Dalam situasi pelanggaran hak asasi manusia secara luas yang diakibatkan oleh tindak pidana korupsi, maka pada umumnya pelanggaran yang terjadi bukanlah pelanggaran langsung melainkan secara tidak langsung. ${ }^{3}$ Salah satu contoh dari pernyataan diatas adalah korupsi terkait dengan pertambangan seperti pertambangan batu giok di Myanmar ${ }^{4}$ atau pertambangan pasir di Indonesia. ${ }^{5}$

Perwakilan Kenya pada 11th International Anti-Corruption Conference (yang selanjutnya disebut dengan The Seoul Findings) di Korea Selatan, Kathuri Murungi, berpendapat bahwa korupsi berskala besar harus ditetapkan sebagai kejahatan terhadap kemanusiaan (crime against humanity, selanjutnya disebut sebagai $\mathrm{CAH}$ ) dengan alasan sama halnya dengan penyiksaan, genosida dan kejahatan terhadap kemanusiaan lainnya, bagi banyak orang di dunia ini korupsi telah merampok martabat kemanusiaan mereka. Konferensi tersebut mendukung seruan perwakilan Kenya dengan menyatakan bahwa mereka mengutuk korupsi sebagai tidak bermoral, tidak adil dan menjijikkan bagi cita-cita kemanusiaan yang diabadikan dalam Universal Declaration of Human Rights (selanjutnya disebut dengan UDHR) dan bahwa semua manusia memiliki hak dasar manusia untuk

\footnotetext{
1 Edy Suandi Hamid [Ed.], Menyingkap Korupsi, Kolusi, Dan Nepotisme Di Indonesia (Aditya Media 1999).[9].

2 Konsideran Undang-Undang Republik Indonesia Nomor 20 Tahun 2001 Tentang Perubahan Atas Undang-Undang Nomor 31 Tahun 1999 Tentang Pemberantasan Tindak Pidana Korupsi.

3 Julio Bacio Terracino, 'Corruption as a Violation of Human Rights' [2008] International Council on Human Rights Policy.[10-11].

4 Global Witness, ‘Jade: Myanmar's ‘Big State Secret' (Global Witness, 2015) <https://www. globalwitness.org/en/campaigns/oil-gas-and-mining/myanmarjade/>. accessed 8 November 2019.

5 Rois Jajeli, 'Tambang Berujung Maut Di Lumajang, ESDM Jatim: Itu Penambangan Ilegal' (Detik News, 2015) <https:/ / news.detik.com/ berita/3032311/tambang-berujung-maut-di-lumajangesdm-jatim-itu-penambangan-ilegal>.accessed 30 Oktober 2019.
} 
hidup dalam masyarakat yang bebas korupsi. ${ }^{6}$

Dengan demikian maka muncul isu hukum mengenai apakah korupsi dapat dikategorikan sebagai CAH. Maka dari itu perlu dilakukan penelitian mengenai konsep dan elemen korupsi dan apakah hal-hal tersebut sesuai dengan konsep dan elemen yang dibutuhkan sebuah kejahatan untuk dapat dikategorikan sebagai CAH. Metode pemelitian yang digunakan dalam penulisan skripsi ini adalah doctrinal research yang bertujuan untuk menemukan kebenaran berdasarkan kesesuaian aturan hukum dengan norma hukum, dan norma hukum dengana asas-asas hukum. ${ }^{7}$ Penelitian ini menggunakan tipe penelitian yuridis normatif. Penelitian yuridis normatif yaitu penelitian yang difokuskan untuk menganalisa suatu permasalahan hukum terhadap norma-norma atau kaidah-kaidah hukum positif yang berlaku. Penelitian yuridis normatif dilakukan dengan cara meneliti bahan pustaka atau data sekunder sebagai bahan dasar untuk diteliti dengan cara mengadakan penelusuran terhadap peraturan-peraturan dan literatur-literatur yang berkaitan dengan permasalahan yang diteliti. ${ }^{8}$

\section{Konsep dan Elemen Korupsi}

Kata "korupsi" berasal dari kosakata bahasa Latin corruptio, dengan kata kerja corrumpere, yang memiliki arti busuk, rusak, menggoyahkan, memutar balik, atau menyogok ${ }^{9}$ dan pada perkembangannya menjadi kata serapan yang memiliki arti berbeda dalam banyak bahasa. Kamus Besar Bahasa Indonesia mengartikan kata korupsi sebagai penyelewengan atau penggelapan uang negara atau perusahaan dan sebagainya untuk kepentingan pribadi maupun golongan. ${ }^{10}$ Dalam bahasa Belanda, kata korupsi (corruptie yang juga disalin menjadi corruptien) mengandung

\footnotetext{
6 '11th International Anti-Corruption Conference' (The Seoul Findings 2003).

7 Peter Mahmud Marzuki, Penelitian Hukum Edisi Revisi (Prenadamedia Group 2016). [47].

8 Soerjono Soekanto dan Sri Mamudji, Penelitian Hukum Normatif: Suatu Tinjauan Singkat (Rajawali Pers 2001).[13-14].

9 Pusat Edukasi Anti Korupsi, 'Apa Itu Korupsi?' (Pusat Edukasi Anti Korupsi) <https:/ /aclc. kpk.go.id/wp-content/uploads/2 018/05/001-apa-itu-korupsi.jpg>. accessed 14 Februari 2019.

10 ibid.
} 
arti perbuatan korup, penyuapan. ${ }^{11}$

The Lexicon Webster Dictionary mengartikan kata korupsi (corruption) sebagai kebusukan, keburukan, kebejatan, ketidakjujuran, dapat disuap, tidak bermoral, penyimpangan dari kesucian, kata-kata atau ucapan yang menghina atau memfitnah. ${ }^{12}$ Sedangkan dalam Black's Law Dictionary, corruption diartikan sebagai “... The act of an official or fiduciary person who unlawfully and wrongfully uses his station or character to procure some benefit for himself or for another person, contrary to duty and the rights of others". ${ }^{13}$

Hingga saat ini belum dapat ditemukan konsensus mengenai definisi korupsi. Hal ini disebabkan perbedaan persepsi dalam menganalisa sifat dari korupsi dan perbuatan-perbuatan dapat dikategorikan sebagi korupsi. Definisi yang paling sering digunakan oleh sarjana yang mempelajari korupsi seperti Rose-Ackermann atau Lambsdorff merupakan definisi yang pertama dicetuskan oleh Joseph Senturia, bahwa korupsi ialah penyalahgunaan kekuatan publik untuk keuntungan pribadi. ${ }^{14}$ Lebih lanjut mengenai definisi diatas, Michael Johnston berpendapat bahwa korupsi adalah penyalahgunaan peran publik untuk kepentingan privat, namun menekankan bahwa kata "publik", "privat", dan "keuntungan" memiliki konteks yang beragam dalam banyak masyarakat dan memiliki berbagai tingkat ambiguitas. ${ }^{15}$ Selain itu, Vito Tanzi mengartikan korupsi sebagai ketidakpatuhan yang disengaja terhadap prinsip kewajaran dan kelaziman usaha ( $\mathrm{rrm}^{\prime} \mathrm{s}$ length principle) dengan tujuan memperoleh sejumlah keuntungan untuk diri sendiri atau untuk individu terkait dari perilaku tersebut. ${ }^{16}$

\footnotetext{
${ }_{11}$ Wijowasito, Kamus Umum Belanda Indonesia (Ikhtiar Baru 1999).[128].

12 Andi Hamzah, Pemberantasan Korupsi Melalui Hukum Pidana Nasional Dan Internasional (Raja Grafindo Persada 2006). [5].

13 Black's Law Dictionary, 'Corruption' (Black's Law Dictionary) <https://thelawdictionary. org/corruption/>. accessed 19 Maret 2019.

${ }^{14}$ Wolfang Muno, 'Clientelist Corruption Networks: Conceptual and Empirical Approaches' [2013] Comparative Governance and Politics.[34].

15 ibid.

16 Boris Begovic, 'Corruption: Concepts, Types, Causes and Consequences' (2005) 26 Center for Opening and Development of Latin America.ibid.[1].
} 
Sebuah definisi lain terhadap korupsi yang digunakan oleh Bank Dunia menyatakan bahwa korupsi adalah penyalahgunaan jabatan publik untuk keuntungan pribadi. Definisi ini menghubungkan korupsi dengan negara, aktivitasnya, intervensi negara terhadap pasar, dan keberadaan sektor publik. Dalam kata lain, definisi ini mengecualikan kemungkinan korupsi dalam sektor privat. ${ }^{17}$ Sedangkan menurut United States Agency for International Development (USAID) Handbookfor Fighting Corruption (1999), korupsi dapat mengambil berbagai macam bentuk karena mencakup pelanggaran sepihak oleh pejabat pemerintah seperti penggelapan dan nepotisme, serta pelanggaran yang menghubungkan aktor publik dan swasta seperti penyuapan, pemerasan, pengaruh penjualan dan penipuan. $^{18}$

Syed Hussein Alatas berpendapat bahwa terdapat tiga tipe fenomena yang tercakup dalam istilah korupsi, yaitu penyuapan (bribery), pemerasan (extortion) dan nepotisme. ${ }^{19}$ Selain itu, Ia juga menjelaskan mengenai ciri-ciri korupsi yang merupakan, namun tidak terbatas pada :

1. Korupsi selalu melibatkan lebih dari satu orang;

2. Pada umumnya melibatkan keserbarahasiaan, kecuali dimana tindak korup itu sudah sedemikian rupa merajalela sehingga para pelaku korupsi merasa tidak perlu lagi melakukannya secara rahasia. Namun demikian, niatan atas dilakukannya korupsi tetap tidak dinyatakan secara tersurat melainkan tetap dirahasiakan;

3. Melibatkan elemen kewajiban dan keuntungan timbal balik;

4. Mereka yang terlibat dalam korupsi akan berusaha untuk berlindung di balik hukum;

5. Mereka yang terlibat dalam korupsi menginginkan sebuah keputusan yang tegas dan mereka juga mampu untuk mempengaruhi keputusan tersebut;

6. Mengandung unsur penipuan, biasanya pada badan publik atau masyarakat umum;

7. Segala bentuk korupsi merupakan sebuah pengkhianatan kepercayaan;

8. Setiap bentuk korupsi melibatkan fungsi ganda yang kontradiktif dari mereka yang melakukan tindakan itu. Contohnya pada korupsi mengenai sebuah

\footnotetext{
${ }_{17}$ Boris Begovic (n 16).

18 International Council on Human Rights Policy, Corruption and Human Rights: Making the Connection ([s.n] 2009). [16].

19 Syed Hussein Alatas, Sosiologi Korupsi: Sebuah Penjelajahan Dengan Data Kontemporer (Lembaga Penelitian, Pendidikan dan Penerangan Ekonomi dan Sosial 1986). [12].
} 
izin. Pemberian izin oleh pejabat yang bersangkutan merupakan fungsi dari jabatannya, namun "perlindungan" kepada pemberi suap bukanlah fungsi jabatannya;

9. Melanggar norma-norma tugas dan pertanggungjawaban tatanan masyarakat dan menempatkan kepentingan khusus diatas kepentingan umum. ${ }^{20}$

Korupsi masih belum memiliki definisi baku yang telah dikodifikasi dalam suatu perjanjian internasional meskipun pentingnya penegakan hukum di bidang korupsi telah menjadi perhatian berbagai organisasi internasional. Hal ini dibuktikan dengan diakuinya bahaya korupsi dan keberadaan perjanjian internasional maupun regional mengenai korupsi dan pemberantasannya. Salah satunya adalah dalam Johannesburg Declaration on Sustainable Development tahun 2002, korupsi diakui sebagai salah satu kondisi global yang merupakan ancaman berat terhadap pembangunan berkelanjutan bersama dengan beberapa ancaman lain diantaranya adalah; pendudukan asing, konflik bersenjata, kejahatan terorganissi, perdagamgan manusia, terorisme, dan lain sebagainya. ${ }^{21} \mathrm{Hal}$ ini merupakan salah satu dasar dibentuknya United Nations Convention against Corruption (UNCAC).

Disebut pada pembukaan UNCAC bahwa dikarenakan kerugian yang ditimbulkan korupsi sangatlah besar, maka hal ini bukan lagi merupakan sebuah masalah lokal melainkan sebuah fenomena transnasional yang memengaruhi seluruh masyarakat dan ekonomi sehingga kooperasi internasional adalah hal yang penting untuk mencegah dan mengontrolnya. Maka dari itu, melalui Resolusi Majelis Umum PBB no. 58/4 31 Oktober 2003, PBB mengesahkan UNCAC sebagai instrumen internasional untuk memerangi korupsi. Atas dasar instruksi tersebut, terdapat beberapa tindakan yang di kriminalisasi dalam UNCAC. Tindakan-tindakan tersebut tidak hanya terdiri dari bentuk korupsi yang dasar (basic) seperi suap-menyuap dan penggelapan dana publik, namun juga tindakan yang dilakukan untuk mendukung/melancarkan korupsi, obstruction of justice, perdagangan pengaruh dan penyembunyian atau pencucian hasil dari korupsi.

\footnotetext{
20 ibid.[12-14].

${ }^{21}$ Pasal 19 Johannesburg Declaration on Sustainable Development (2002).
} 
Selain itu, UNCAC juga mengatur mengenai korupsi di bagian swasta. ${ }^{22}$ Tindakantindakan yang dikriminalisasi oleh UNCAC adalah sebagai berikut:

1. Suap pasif dan aktif terhadap pejabat publik nasional (Pasal 15);

2. Suap pasif dan aktif terhadap pejabat publik asing dan pejabat organisasi internasional publik (Pasal 16);

3. Penggelapan, penyelewengan atau pengalihan harta lainnya oleh pejabat publik (Pasal 17);

4. Perdagangan dalam pengaruh (Pasal 18);

5. Penyalahgunaan fungsi (Pasal 19);

6. Pengayaan terlarang (Pasal 20);

7. Suap di sektor swasta (Pasal 21);

8. Penggelapan properti di sektor swasta (Pasal 22);

9. Pencucian uang hasil kejahatan (Pasal 23);

10. Penyembunyian barang hasil kejahatan (Pasal 24); dan

11. Penghalangan atas keadilan (Pasal 25);

12. Partisipasi dan percobaan (Pasal 27).

Pasal-pasal sebagaimana disebutkan diatas mencakup sisi supply dan demand dalam tindak pidana korupsi. ${ }^{23}$ UNCAC juga mencakup berbagai macam individu yang termasuk dalam yurisdiksinya yaitu pejabat pemerintah, ${ }^{24}$ organisasi internasional publik, ${ }^{25}$ dan sektor swasta. ${ }^{26}$ Dalam pengaturan mengenai kriminalisasi tindakan-tindakan korup, UNCAC memberikan kewajiban pada negara-negara anggotanya untuk menerapkan hukum sebagaimana diatur dalam perjanjian ini dengan menggunakan kata "shall adopt" 27 dan anjuran untuk menerapkan hukum yang diaturkan dengan penggunaan kata "shall consider" 28 dalam klausulanya. ${ }^{29}$

Klausul yang bersifat wajib untuk dikriminalisasi oleh UNCAC ini harus ditetapkan sebagai tindak pidana dalam hukum nasional negara anggotanya dengan mencakup semua elemen yang diperlukan dalam pelanggaran, tidak

\footnotetext{
${ }^{22}$ United Nations Office on Drugs and Crime Division for Treaty Affairs, 'Legislative Guide for the Implementation of the United Nations Convention against Corruption' (2006) <https:// www.unodc.org/pdf/corruption/CoC_LegislativeGuide.pdf>. accessed 20 Maret 2019.[2].

${ }^{23}$ Thomas R. Snider dan Won Kidane, 'Pasal 15-20 UNCAC Dalam Combating Corruption through International Law in Africa: A Comparative Analysis' (2007) 40 Cornell International Law Journal.[708].

${ }^{24}$ Pasal 2 Huruf (a) Dan Huruf (b) UNCAC.

${ }_{25}$ Pasal 2 Huruf (c) UNCAC.

${ }^{26}$ Pasal 15-16 Dan Pasal 21-22 UNCAC.

27 Pasal 15, Pasal 16 (1), Pasal 17, Pasal 23 Dan Pasal 25 UNCAC.

28 Pasal 16 (2), Pasal 18-22 Dan Pasal 24 UNCAC.

${ }^{29}$ Thomas R. Snider dan Won Kidane (n 23)., Loc.cit.
} 
dengan langkah selain hukum yang hanya akan menjadi tambahan untuk undangundang. ${ }^{30}$ Contohnya dalam Pasal 15 UNCAC diatur suap-menyuap sebagai salah satu klausul yang bersifat wajib, ${ }^{31}$ sehingga seluruh elemen dari tindak pidana ini harus dikriminalisasi oleh hukum nasional negara anggota UNCAC. Adapun elemen dari tindak pidana ini yang wajib untuk diatur terdiri dari penyuapan aktif $^{32}$ dan penyuapan pasif. ${ }^{33}$

\section{Konsep dan Elemen CAH}

Istilah CAH pertama muncul ketika pemerintah Inggris, Prancis dan Rusia mengeluarkan deklarasi bersama mengenai pembantaian populasi Armenia di Turki pada tahun 1915. Mereka menyebut tindakan Turki tersebut sebagai "crime against civilization and humanity" dan bahwa pemerintah Turki harus bertanggung jawab atas tindakannya. Deklarasi ini didorong oleh dahsyatnya kejahatan yang dilakukan oleh pemerintah Turki pada penduduk Armenia. Yang dianggap sebagai sebuah kebaruan dari situasi ini dibandingkan dengan war crime adalah bahwa kekejaman tersebut dilakukan oleh warga sebuah negara terhadap sesama warga negara tersebut, bukan dari warga negara asing. ${ }^{34} \mathrm{CAH}$ kembali muncul mengikuti kejahatan yang dilakukan oleh Nazi Jerman kepada warga negaranya sendiri. Pada Maret 1944, Presiden Amerika Serikat yaitu Franklin D. Roosevelt mengeluarkan pernyataan yang berisi celaan terhadap pemimpin partai Nazi, Adolf Hitler, bahwa Ia telah melakukan CAH atas nama warga Jerman. ${ }^{35}$

\footnotetext{
${ }^{30}$ United Nations Office on Drugs and Crime Division for Treaty Affairs (n 22). Op.cit.[82].

31 "Each State Party shall adopt [huruf tebal dari penulis] such legislative and other measures as may be necessary...." Pasal 15 UNCAC.

32 "...defined as the promise, offering or giving to a public official of an undue advantage, in order to act or refrain from acting in matters relevant to official duties," dalam United Nations Office on Drugs and Crime Division for Treaty Affairs, Op.cit.[80].

33 "....defined as the solicitation or acceptance by a public official of an undue advantage, in order to act or refrain from acting in matters relevant to official duties," dalam United Nations Office on Drugs and Crime Division for Treaty Affairs, Op.cit.[81].

34 Andrzej Bryl, 'Crimes against Humanity - in Pursuit of an International Convention' <http://www.bibliotekacyfrowa.pl/Content/54577/04_Andrzej_Bryl. pdf>. accessed 1 September 2019.[2].

35 Matthew Lippman, 'Crimes Against Humanity' (1997) 17 Boston College Thirld World Law Journal.[8].
} 
Dalam usaha mengadili Jerman atas pelanggaran perang dan kejahatannya yang luar biasa di masa itu, maka para pemenang perang dunia kedua mengembangkan dan menandatangani London Agreement yang menjadi dasar untuk mengadili penjahat perang Jerman dalam International Military Tribunal at Nuremberg (pengadilan Nuremberg). ${ }^{36}$ London Agreement ini adalah instrumen internasional pertama yang mengatur $\mathrm{CAH}$ dalam hukum positif internasional. ${ }^{37}$

Tidak lama setelah London Agreement dan pengadilan pengadilan Nuremberg dimulai, International Military Tribunal for the Far East dibentuk melalui sebuah deklarasi oleh Jendral Douglas McArthur dari Amerika Serikat untuk mengadili Jepang pada tahun 1946. Pengadilan ini menggunakan pengadilan Nuremberg sebagai modelnya dan membentuk tiga kategori kejahatan yang digunakan untuk menuntut Jepang yaitu crime against peace (kelas A), conventional war crime (kelas B), CAH (kelas C). Kedua pengadilan ad hoc ini menetapkan bahwa pertanggung jawaban pidana individu diakui dalam hukum internasional, terlepas dari hukum nasional, dan dapat mengadili kepala negara. ${ }^{38}$

Pada tahun 1993 dan 1994 berturut-turut, Dewan Keamanan PBB membentuk dua pengadilan internasional ad hoc yang pada statutanya masing-masing memiliki pengertian $\mathrm{CAH}$ yang berbeda. Yang pertama adalah International Criminal Tribunal for the former Yugoslavia (ICTY) yang dibentuk pada bulan Mei 1993 oleh PBB untuk kejahatan perang dan kejahatan lainnya pada perang di yang dulunya adalah Yugoslavia. ${ }^{39}$ Selanjutnya pada bulan November 1994, PBB membentuk International Criminal Tribunal for Rwanda (ICTR) sebagai respon terhadap genosida dan pelanggaran hukum humaniter internasional di kawasan Rwanda dan negara-negara tetangganya. ${ }^{40}$ Selanjutnya pada tahun 1998 , The Rome

\footnotetext{
${ }^{36}$ Andrzej Bryl (n 34)., Op.cit.[3].

${ }_{37}$ M. Cherif Bassiouni, Crimes Against Humanity: Historical Evolution and Contemporary Application (Cambridge University Press 2011). [95].

38 J. Alton Hosch, 'More About the IMFTE' <http://libguides.law.uga.edu/c. php?g=177176\&p= 1164581>. accessed 5 September 2019 .

39 United Nations International Residual Mechanism for Criminal Tribunals, 'About the ICTY' <http:/ / www.icty.org/en/about>. accessed 25 Juli 2019.

40 United Nations International Residual Mechanism for Criminal Tribunals, 'The ICTR in Brief' <https://unictr.irmct.org/en/tribunal>. accessed 25 Juli 2019.
} 
Hana Ramiza: Korupsi State Capture...

Statute of International Criminal Court (Statuta Roma) dibentuk sebagai dasar untuk mendirikan International Criminal Court (ICC) sehingga perjanjian ini juga dikenal sebagai Statuta ICC. ${ }^{41}$ Definisi CAH menurut Statuta Roma adalah sebagai berikut: .... any of the following acts when committed as part of a widespread or systematic attack directed against any civilian population, with knowledge of the attack:

(a) Murder;

(b) Extermination;

(c) Enslavement;

(d) Deportation or forcible transfer of population;

(e) Imprisonment or other severe deprivation of physical liberty in violation of fundamental rules of international law;

(f) Torture;

(g) Rape, sexual slavery, enforced prostitution, forced pregnancy, enforced sterilization, or any other form of sexual violence of comparable gravity;

(h) Persecution against any identifiable group or collectivity on political, racial, national, ethnic, cultural, religious, gender as defined in paragraph 3, or other grounds that are universally recognized as impermissible under international law, in connection with any act referred to in this paragraph or any crime within the jurisdiction of the Court;

(i) Enforced disappearance of persons;

(j) The crime of apartheid;

(k) Other inhumane acts of a similar character intentionally causing great suffering, or serious injury to body or to mental or physical health. ${ }^{42}$

Definisi kejahatan dalam Statuta Roma belum mewakili keseluruhan gambaran mengenai kejahatan tersebut. Definisi tersebut harus dibaca bersama dengan prinsip-prinsip umum sebagaimana diatur dalam Bagian 3 Statuta Roma dan dijabarkan lebih lanjut dalam dokumen Elements of Crime (EoC) yang akan membantu dalam menafsirkan dan menerapkan ketentuan tentang pelanggaran sebagaimana diatur dalam pasar 21(1) jo. Pasal 9 Statuta Roma. ${ }^{43}$

Dalam pasal 7(1) Statuta Roma diatur bahwa CAH memiliki elemen $a$ widespread or systematic attack directed against any civilian population dan knowledge of the attack. Dalam dokumen Elements of Crime dijelaskan lebih lanjut bahwa

${ }^{41}$ Ida Lim, 'Rome Statute: What Is It? Will Agong's Immunity Be At Risk?' (malaymail, 2019) <https://www.malaymail.com/news/malaysia/2019/03/25/rome-statute-what-is-it-will-agongsimmunit y-be-at-risk/1736067>. accessed 10 September 2019.

42 Pasal 7(1) Statuta Roma.

${ }^{43}$ Robert Cryer, An Introduction to International Criminal Law and Procedure (Cambridge University Press 2007).[125]. 
dalam terjadinya $\mathrm{CAH}$, diperlukan partisipasi dalam dan pengetahuan mengenai serangan yang meluas atau sistematis terhadap sebuah populasi masyarakat sipil. ${ }^{44}$ Namun perlu diingat bahwa elemen "pengetahuan mengenai serangan" tersebut tidak boleh ditafsirkan sebagai seseorang harus mengetahui segala karakteristik atau detail yang tepat mengenai rencana atau kebijakan oleh negara atau organisasi tentang serangan tersebut. Maksud dari klausa tersebut akan terpenuhi cukup dengan keinginan dari pelaku untuk melanjutkan serangan tersebut. ${ }^{45}$

Munculnya dan berkembangnya konsep $\mathrm{CAH}$ menunjukkan bahwa kemanusiaan (humanity) merupakan identitas yang melekat pada manusia dan memberikan sebuah alasan normatif untuk melakukan suatu tindakan atau tidak melakukan suatu tindakan tertentu. Hal ini menempatkan norma humanity sebagai norma yang valid dan norma hukum yang sah, tidak lagi sekedar norma moral yang konsekuensinya terbatas pada kecaman moral melainkan penuntutan hukum. ${ }^{46}$

Kemunculan istilah $\mathrm{CAH}$ mengikuti berakhirnya perang dunia kedua menimbulkan setidaknya dua pikiran mengenai kejamnya kejahatan ini. Pertama adalah istilah $\mathrm{CAH}$ menunjukkan bahwa kejahatan ini merugikan tidak hanya para korban dan komunitas sekitar korban tersebut, melainkan merugikan seluruh umat manusia terlepas dari komunitasnya. ${ }^{47}$ Yang kedua adalah bahwa istilah CAH menunjukkan bahwa kejahatan tersebut telah melanggar inti kemanusiaan yang dimiliki dan melekat pada seluruh manusia dan yang membedakan kita dari makhluk hidup lainnya. ${ }^{48}$ Artinya kejahatan ini mencakup kedua arti dari kata kemanusiaan yaitu umat manusia (human-kind) dan sifat manusia (humane-ness). ${ }^{49}$

\footnotetext{
${ }^{44}$ International Criminal Court, Elements of Crimes ([s.n] 2010).[5].

45 ibid.

${ }^{46}$ Xunwu Chen, 'The Concept of Crime against Humanity and the Spirit of Our Time' (2013) 2 Journal of East-West Thought. [26].

${ }^{47}$ David Luban, 'A Theory of Crime Against Humanity' (2004) 29 The Yale Journal of International Law.

48 ibid.

49 Christopher Macleod, 'Towards a Philosophical Account of Crimes against Humanity' (2010) 21 The European Journal of International law.[283].
} 


\section{State Capture dan Korupsi sebagai CAH}

Terdapat tiga kemungkinan korupsi dapat melanggar HAM, yaitu pelanggaran langsung, pelanggaran tidak langsung dimana korupsi merupakan faktor penting atas terjadinya pelanggaran HAM dan pelanggaran dimana korupsi hanyalah merupakan salah satu dari banyak faktor penyebabnya. Dalam kemungkinan yang pertama, korupsiakan secara langsung melanggarHAMapabila tindakan korup tersebut digunakan sebagai alat untuk melanggar HAM seseorang. Contohnya adalah tindakan suap-menyuap pada hakim untuk mempengaruhi putusan hakim tersebut terhadap perkara yang ditugaskan kepadanya. Situasi lain dari pelanggaran HAM langsung oleh korupsi ini juga dapat terjadi apabila sebuah negara gagal dalam melakukan tugasnya sehingga warga negaranya tidak dapat mengakses suatu hal yang sudah menjadi haknya, dan jalan untuk mendapatkan akses terhadap haknya tersebut adalah melalui korupsi. Contohnya adalah ketika seorang murid yang memiliki kemampuan untuk menempuh suatu jenjang pendidikan, namun oleh pihak pemegang kekuasaan dipersulit sehingga satu-satunya cara untuk dapat menempuh pendidikan tersebut hanya apabila murid tersebut menyuap pihak pemegang kekuasaan. ${ }^{50}$

Dalam situasi lain, korupsi akan menjadi faktor penting yang berkontribusi terhadap serangkaian kejadian yang akan berakhir pada sebuah pelanggaran HAM. Dalam hal ini, HAM akan dilanggar oleh sebuah kejadian yang berasal dari sebuah tindakan korup dan tindakan korup tersebut adalah kondisi yang diperlukan dalam terjadinya pelanggaran. Kemungkinan ketiga adalah ketika korupsi merupakan salah satu faktor terjadinya sebuah pelanggaran HAM dimana tindakan korup bukan satu-satunya alasan atau faktor penentu dari pelanggaran HAM tersebut, melainkan sebuah bagian kecil. ${ }^{51}$

Untuk mengkualifikasikan korupsi sebagai $\mathrm{CAH}$, maka dibutuhkan hubungan kausalitas antara tindakan korupsi dan pelanggaran HAM yang terjadi. Selain itu, sebagaimana diatur dalam pasal 7(1) Statuta Roma, CAH mensyaratkan

\footnotetext{
${ }^{50}$ Julio Bacio Terracino (n 3)., Op.cit.[27].

51 ibid.[27-28].
} 
serangan yang meluas atau sistematik dengan pengetahuan mengenai serangan tersebut. Dengan demikian, maka dapat disimpulkan tidak semua bentuk korupsi dapat dikualifikasikan sebagai CAH. Salah satu bentuk korupsi yang dapat dikategorikan sebagai CAH adalah korupsi dalam bentuk state capture.

Transparansi Internasional mendefinisikan state capture sebagai situasi dimana individu yang memiliki kekuasaan, institusi, perusahaan atau kelompok di dalam atau luar suatu negara menggunakan korupsi untuk membentuk kebijakan sebuatu negara, lingkungan hukumnya dan ekonominya demi menguntungkan kepentingan pribadi mereka. ${ }^{52}$ Menurut mereka state capture adalah salah satu bentuk korupsi yang paling dapat menembus segala lini institusi publik seperti instansi legislatif, eksekutif, yuridis dan badan pengatur baik dalam tingkatan federal maupun lokal. State capture juga dapat timbul dari adanya persamaan kepentingan antara pelaku bisnis tertentu dengan elit-elit politik melalui hubungan keluarga, pertemanan dan kepemilikan yang saling terkait atas aset ekonomi..$^{53}$

Meskipun menurut pengetian umum korupsi dan state capture adalah hal yang sama, namun terdapat suatu perbedaan diantara keduanya. Korupsi umumnya ditujukan untuk mengubah implementasi dari hukum, peraturan, atau kenijakan yang sudah ada dan berlaku sedangkan state capture mengacu pada tindakan korup yang dilakukan sebagai usaha untuk mempengaruhi bagaimana hukum, peraturan dan kebijakan tersebut dibentuk. ${ }^{54}$

Solveig Richter menerangkan bahwa terdapat empat fitur utama dari state capture. Yang pertama, individu atau entitas bisnis yang memiliki maksud untuk "menangkap" (capture) suatu institusi negara atau orang-orang yang memiliki kekuasaan akan menarget pejabat yang memiliki kuasa untuk membentuk hukum, pertauran atau keputusan kebijakan, tidak menarget birokrasi di bidang

\footnotetext{
52 Transparansi Internasional, The Anti-Corruption Plain Language Guide ([s.n] 2009).[43].

53 Maira Martini, 'State Capture: An Overview' (Transparansi Internasional, 2014) <https:// www.transparency.org/files/content/corruptionqas/State_capture_an_overview_2014.pdf>. accessed 5 Oktober 2019.[2].

${ }^{54}$ Lily Evelina Sitorus, 'State Capture: Is It a Crime? How the World Perceive It' (2011) 2 Indonesia Law Review.[46-47].
} 
administrative yang bertugas mengimplementasikan hukum dan peraturan yang sudah ada dan berlaku..$^{55}$

Yang kedua adalah bahwa state capture merupakan korupsi berbasis jaringan yang berkembang di jaringan sosial dan politik melalui klientelisme dan patronage. Jaringan tersebut didasarkan pada aturan informal antar anggota yang didirikan atas dasar dominasi otoritas atau timbal balik dan kesetiaan, yang selanjutnya membuka jalan bagi keterlibatan swasta, negara atau non-negara dan sekelompok kepentingan lainnya dalam pembentukan peraturan yang mana beberapa diantaranya mungkin tidak perpartisipasi dalam perilaku korup tersebut. ${ }^{56}$

Yang ketiga adalah bahwa tidak seperti korupsi yang motif utamanya adalah keuntungan pribadi dalam melakukan perilaku korup, tujuan utama diatas keuntungan pribadi dari pelaku state capture adalah untuk mendapatkan akses kekuasaan atau untuk mempertahankan kekuasaan yang dimiliki. Bahkan pada negara-negara dimana state capture sudah sangat mengakar, dapat ditemukan intimidasi dan bahkan kekerasan. Dan yang terakhir adalah bahwa penggunaan kamuflase lembaga formal untuk mewakili kepentingan mereka. Partisipasi dari berbagai kelompok kepentingan dan masyarakat sipil serta keterlibatan media dan partai politik adalah hal yang penting dalam demokrasi, namun media dan partai politik dapat, baik secara sadar atau tidak sadar, berlaku sebagai perpanjangan tangan pihak-pihak swasta atau pribadi yang memiliki kekuasaan. ${ }^{57}$

Bahaya utama dari state capture adalah bahwa pengambilan keputusan tidak lagi mempertimbangkan kepentingan publik melainkan menjadi lebih berpihak pada kepentingan kelompok tertentu. Pembentukan hukum, kebijakan dan sebagainya dirancang sedemikian rupa untuk menguntungkan kepentingan sekelompok tertentu dan kebanyakan menimbulkan kerugian terhadap kelompok dan perusahaan yang lebih kecil dan masyarakat pada umunya. Tipe

${ }^{55}$ Maurice O. Dassah, 'Theoritical Analysis of State Capture and Its Manifestation as A Governance Problem in South Africa' (2018) 14 The Journal for Transdiciplinary Research in Southern Africa.[4].

$$
\begin{aligned}
& { }_{56} \text { ibid. } \\
& 57 \text { ibid.[5]. }
\end{aligned}
$$


korupsi ini dapat benar-benar mempengaruhi perkembangan ekonomi, kualitas peraturan, ketentuan pelayanan publik, kualitas pendidikan dan layanan kesehatan, keputusan mengenai infrastruktur, dan bahkan lingkungan dan kesehatan publik..$^{58}$

Dalam pasal 7(1) Statuta Roma diatur bahwa CAH memiliki elemen $a$ widespread or systematic attack directed against any civilian population dan knowledge of the attack. Dalam dokumen Elements of Crime dijelaskan lebih lanjut bahwa dalam terjadinya $\mathrm{CAH}$, diperlukan partisipasi dalam dan pengetahuan mengenai serangan yang meluas atau sistematis terhadap sebuah populasi masyarakat sipil..$^{59}$ Namun perlu diingat bahwa elemen "pengetahuan mengenai serangan" tersebut tidak boleh ditafsirkan sebagai seseorang harus mengetahui segala karakteristik atau detail yang tepat mengenai rencana atau kebijakan oleh negara atau organisasi tentang serangan tersebut. Maksud dari klausa tersebut akan terpenuhi cukup dengan keinginan dari pelaku untuk melanjutkan serangan tersebut. ${ }^{60}$

Berkaca pada uraian di atas, dapat diketahui bahwa state capture dilakukan dengan sistematik dan terencana dengan bahaya yang memiliki cakupan luas dan dilaksanakan dengan kesadaran pelaku dalam usahanya untuk mendapatkan atau mempertahankan kekuasaan dan mendapatkan keuntungan dari itu. Dengan demikian, maka dapat disimpulkan bahwa korupsi, khususnya state capture, memenuhi elemen yang dibutuhkan sebagai $\mathrm{CAH}$.

\section{Kesimpulan}

State capture dilakukan secara sistematik dan terencana, menunjukkan bahwa kejahatan ini hanya dapat dilakukan dengan kesadaran pelaku dalam usahanya untuk mendapatkan atau mempertahankan baik keuntungan maupun kekuasannya dalam suatu negara yang sudah "tertangkap". Kejahatan ini juga memiliki ancaman bahaya dengan cakupan yang luas baik secara wilayah geografis

\footnotetext{
${ }^{58}$ Maira Martini (n 53)., Loc. cit.

59 International Criminal Court (n 44)., Loc.cit.

60 ibid.
} 
maupun jumlah korban dan diikuti juga oleh pelanggaran HAM berat lainnya sehingga menujukkan bahwa korupsi, khususnya state capture telah memenuhi elemen yang dibutuhkan untuk dapat dikategorikan sebagai CAH.

\section{Daftar Bacaan}

\section{Buku}

Andi Hamzah, Pemberantasan Korupsi Melalui Hukum Pidana Nasional dan Internasional (Raja Grafindo Persada 2006).

Edy Suandi Hamid [Ed.], Menyingkap Korupsi, Kolusi, dan Nepotisme di Indonesia (Aditya Media 1999).

International Council on Human Rights Policy, Corruption and Human Rights: Making the Connection ([s.n] 2009).

M. Cherif Bassiouni, Crimes Against Humanity: Historical Evolution and Contemporary Application, (Cambridge University Press 2011).

Peter Mahmud Marzuki, Penelitian Hukum Edisi Revisi (Prenadamedia Group 2016).

Robert Cryer [et., al.], An Introduction to International Criminal Law and Procedure, Cambridge University Press 2007).

Soerjono Soekanto dan Sri Mamudji, Penelitian Hukum Normatif : Suatu Tinjauan Singkat (Rajawali Pers 2001).

Syed Hussein Alatas, Sosiologi Korupsi: Sebuah Penjelajahan dengan Data Kontemporer (Lembaga Penelitian, Pendidikan dan Penerangan Ekonomi dan Sosial 1986).

Transparansi Internasional, The Anti-Corruption Plain Language Guide ([s.n] 2009). Wijowasito, Kamus Umum Belanda Indonesia (Ikhtiar Baru 1999).

\section{Jurnal}

Boris Begovic, 'Corruption: Concepts, Types, Causes and Consequences' (2005) 26 Center for Opening and Development of Latin America.

Christopher Macleod, 'Towards a Philosophical Account of Crimes against Humanity' (2010) 21 The European Journal of International law.

David Luban, A Theory of Crime Against Humanity' (2004) 29 The Yale Journal of International Law. 
Julio Bacio Terracino, 'Corruption as a Violation of Human Rights' (2008) International Council on Human Rights Policy.

Lily Evelina Sitorus, 'State Capture: Is It a Crime? How the World Perceive It' (2011) 2 Indonesia Law Review.

Matthew Lippman, 'Crimes Against Humanity' (1997) 17 Boston College Thirld World Law Journal.

Maurice O. Dassah, 'Theoritical Analysis of State Capture and Its Manifestation as A Governance Problem in South Africa' (2018) 14 The Journal for Transdiciplinary Research in Southern Africa.

Thomas R. Snider dan Won Kidane, 'Combating Corruption through International Law in Africa: A Comparative Analysis' (2007) 40 Cornell International Law Journal.

Wolfang Muno, 'Clientelist Corruption Networks: Conceptual and Empirical Approaches' (2013) Special Issue 3 Comparative Governance and Politics.

Xunwu Chen, 'The Concept of Crime against Humanity and the Spirit of Our Time' (2013) 2 Journal of East-West Thought.

\section{Laman}

Andrzej Bryl, 'Crimes against Humanity - in Pursuit of an International Convention' <http://www.bibliotekacyfrowa.pl/Content/54577/04_Andrzej_Bryl. pdf $>$ accessed 1 September 2019.

Black'sLaw Dictionary, 'Corruption' < https://thelawdictionary.org/corruption/> accessed 19 Maret 2019.

Global Witness, 'Jade: Myanmar's 'Big State Secret', (Global Witness, 2015) <https://www.globalwitness.org/en/campaigns/oil-gas-and-mining/ myanmarjad e/> accessed 8 November 2019.

Ida Lim, 'RomeStatute: What Is It? Will Agong's Immunity Be At Risk?', (malaymail, 2019) <https://www.malaymail.com/news/ malaysia/2019/03/25/romestatute-what-is-it-will-agongs-immunity-be-at-risk/1736067> accessed 10 September 2019.

J. Alton Hosch, 'More About the IMFTE', <http://libguides.law.uga.edu/c.php? $g=177176 \& p=1164581>$ accessed 5 September 2019.

Maira Martini, 'State Capture: An Overview', (Transparansi Internasional, 2014) 
<https://www.transparency.org/files/content/corruptionqas/State_ capture_an_overview_2014.pdf $>$ accessed 5 Oktober 2019.

Pusat Edukasi Anti Korupsi, 'Apa Itu Korupsi?' <https://aclc. kpk.go.id/wpcontent/uploads/2018/05/001-apa-itu-korupsi.jpg> accessed 14 Februari 2019.

Rois Jajeli, 'Tambang Berujung Maut di Lumajang, ESDM Jatim: Itu Penambangan Ilegal', (Detik News, 2015 <https://news.detik.com/berita/3032311/ tambang-berujung-maut-di-lumajang-esdm-jatim-itu-penambangan-ilegal> accessed 30 Oktober 2019.

United Nations International Residual Mechanism for Criminal Tribunals, 'About the ICTY', <http:/ / www.icty.org/en/about> accessed 25 Juli 2019.

United Nations International Residual Mechanism for Criminal Tribunals, 'The ICTR in Brief', <https:// unictr.irmct.org/en/tribunal> accessed 25 Juli 2019.

United Nations Office on Drugs and Crime Division for Treaty Affairs, 'Legislative Guide for the Implementation of the United Nations Convention against Corruption' (2006) <https://www.unodc.org/pdf/corruption/CoC_ Legislative Guide.pdf> accessed 20 Maret 2019.

\section{Perundangan-undangan}

Undang-undang Republik Indonesia Nomor 20 Tahun 2001 tentang Perubahan atas Undang-undang Nomor 31 Tahun 1999 tentang Pemberantasan Tindak Pidana Korupsi (Lembaran Negara RI Tahun 2001 Nomor 134, Tambahan Lembaran, Tambahan Lembaran Negara RI Nomor 4150).

Pasal 19 Johannesburg Declaration on Sustainable Development.2002.

11th International Anti-Corruption Conference, The Seoul Findings, Seoul, Mei 2003.

International Criminal Court, Elements of Crimes, International Criminal Court, Den Haag, 2010, h. 5.

How to cite: Hana Ramiza, 'Korupsi State Capture Sebagai Crime Against Humanity' (2020) Vol. 3 No. 2 Media Iuris. 